\title{
THE ROLE OF FAMILY RELATIONS, SPIRITUALITY AND ENTERTAINMENT IN MODERATING PEER INFLUENCE AND DRUG USE AMONG STUDENTS OF EIGHT UNIVERSITIES FROM FIVE COUNTRIES IN LATIN AMERICA AND THREE FROM THE CARIBBEAN
}

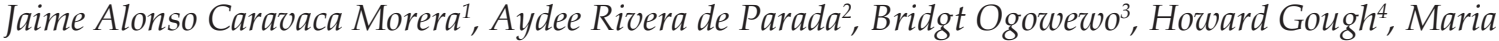 \\ Magaly Scott Alava ${ }^{5}$, Maria Terezinha Zeferino ${ }^{6}$, Mia Jules', Rashalee Mitchell ${ }^{8}$, Rolando Salazar Sarmiento ${ }^{9}$, \\ Anadergh Barbosa-Branco ${ }^{10}$, Akwatu Khenti ${ }^{11}$
}

${ }^{1}$ M.Sc. Associate Professor, School of Nursing, University of Costa Rica. San Jose, Costa Rica. E-mail: jacamorera@hotmail.com

2 Doctoral Student, Associate Professor, School of Education, Evangelica University of El Salvador. San Salvador, El Salvador. E-mail: aydee.rivera@gmail.com.

3 Ph.D. Associate Professor, School of Education, University of Guyana. Georgetown, Guyana. E-mail: bridgy2006@yahoo.com

${ }^{4}$ Doctoral Student, Former Faculty of University of West Indies, Mona Campus. Kingston, Jamaica. E-mail: misemiewasdere@ yahoo.com.

5 Ph.D. Associate Professor, School of Nursing, Technical University. Manabi, Ecuador. E-mail: mariamagaliscott@hotmail.com

${ }^{6}$ Ph.D. Associate Professor, Nursing Department, Federal University of Santa Catarina. Florianopolis, Santa Catarina, Brazil. E-mail:tzeferino@ccs.ufsc.br

7 Doctoral Student, Assistant Professor, Psychology Department, University West Indies, Cave Hill Campus. Barabados. E-mail: miajules@hotmail.com

8 M.Sc. Assistante Professor, Psychology Department, University of West Indies, Mona Campus. Kingston, Jamaica. E-mail: dimps2020@yahoo.com

9 M.Sc. Associate Professor, Psychology, Health Science University Foundation. Bogota, Colombia. E-mail: rsalazarsarmiento@ yahoo.com

${ }^{10}$ Ph.D. Associate Professor, University of Brasilia (retired), CAMH External Consultant. Toronto, Canada. E-mail: anadergh@ hotmail.com

${ }^{11}$ Doctoral Student, Associate Professor, University of Toronto, Director Transformative Global Health Office. Toronto, Canada. E-mail: akwatu_khenti@camh.net

\begin{abstract}
This study is a multi-centric investigation on the role of family relations, spirituality and entertainment in moderating the relationship between peer influence and drug use (licit and illicit) among students from eight universities from five countries in LatinAmerica and three from the Caribbean. The sample was composed by 2198 university students from faculties of Social Sciences and Humanities/Health Sciences. Drug use was the dependent variable and the level of peer influence (number of friends who use drugs) was the independent variable. The results showed that problematic family relationship, high number of party-based entertainment and high number of friends on drugs use (peer influence) increased the odds of youths using illicit drugs. The only interaction statistically significant for licit and illicit drug use was party-based entertainment and friends on drugs. The use of licit drugs presented large variability among universities in the sample, potentially influenced by cultural/religious aspects.
\end{abstract}

DESCRIPTORS: Drug abuse. University. Family. Cultural factors. Peer group.

\section{O PAPEL DAS RELAÇÕES FAMILIARES, ESPIRITUALIDADE E DIVERSÃO COMO MODERADORES ENTRE A INFLUÊNCIA DE PARES E O USO DE DROGAS ENTRE ESTUDANTES DE OITO UNIVERSIDADES DE CINCO PAISES DA AMÉRICA LATINA E TRÊS DO CARIBE}

\footnotetext{
RESUMO: Trata-se de estudo multicêntrico, que analisa o papel das relações familiares, espiritualidade e entretenimento-festas como moderadores da relação entre a influência dos pares e o uso de drogas entre estudantes de oito universidades de cinco países da América Latina e três do Caribe. A amostra foi composta por 2198 estudantes de Faculdades de Ciências Sociais e de Ciências da Saúde. Uso de drogas foi a variável dependente e influência dos pares (número de amigos usando drogas), a independente. Os resultados mostraram que relações familiares problemáticas, participar de muitas festas e ter muitos amigos usando drogas aumentou a chance dos estudantes universitários da amostra usarem drogas ilícitas. A única interação estatisticamente significante para o uso de drogas lícitas ou ilícitas foi o entretenimento-festas/amigos usando drogas. O uso de drogas lícitas apresentou grande variabilidade entre as universidades da amostra, potencialmente influenciada por aspectos culturais/religiosos.
}

DESCRITORES: Abuso de drogas. Universidade. Família. Fatores culturais. Grupo de pares. 


\title{
EL PAPEL DE LAS RELACIONES FAMILIARES, ESPIRITUALIDAD Y DIVERSIÓN COMO MODERADORES ENTRE LA INFLUENCIA DE PARES Y EL USO DE DROGAS ENTRE ESTUDIANTES DE OCHO UNIVERSIDADES DE CINCO PAÍSES DE AMERICA LATINA Y TRES DEL CARIBE
}

\begin{abstract}
RESUMEN: Estudio multicéntrico que analiza el papel de las relaciones familiares, la espiritualidad y la diversión-fiestas como moderadores de la relación entre la influencia de pares y el uso de drogas entre estudiantes de ocho universidades de cinco países de America Latina y tres del Caribe. La muestra fue composta de 2198 estudiantes de Facultades de Ciencias Sociales y de Ciencias de la Salud. El Uso de drogas fue la variable dependiente y la influencia de pares (número de alumnos usando drogas) la independiente. Los resultados indicaron que las relaciones familiares problemáticas, participar de muchas fiestas y tener muchos amigos utilizando drogas aumentó la oportunidad de los estudiantes de la muestra a utilizaren drogas ilícitas. La única interacción estadísticamente significante para el uso de drogas lícitas e ilícitas fue la diversión/fiestas/amigos usando drogas. El uso de drogas lícitas presenta grande variabilidad entre las universidades de la muestra, potencialmente influenciada por aspectos culturales/religiosos.

DESCRIPTORES: Consumo de drogas. Universidad. Familia. Factores culturales. Grupo paritario.
\end{abstract}

\section{INTRODUCTION}

Drug use has been a public health issue of broader community concern for some time. However, despite countries' proclaims regarding successful initiatives to control the demand for illicit drugs, drug abuse throughout the world continues to grow. There is also the recognition that illicit drug use particularly in some developing countries has increased dramatically and this is especially true in Latin America and the Caribbean. ${ }^{1-2}$

In 2010, $\mathrm{UNODC}^{3}$ reported that the global market for illicit drugs is valued at over US\$ 300 billion annually. In this context, a research study ${ }^{4}$ on the prevalence of illicit drugs showed an unprecedented increase in drug use by diverse groups of young people from all socioeconomic backgrounds. This appears to be occurring within a scenario of increasing rates of other social challenges such as youth crime and violence, family disorganization, domestic or family violence, among others.

The consumption of drugs by youth is also recognized a behavior which involves culturally mediated learning processes ${ }^{5}$ cultural agents of socialization such as the family, peers, religion and the entertainment industry are among the social institutions from which young adults and adolescents cognitively assimilate information and become influenced, and, by extension, influence the behaviors of others. ${ }^{6}$ Therefore, cultural factors have the potential to affect the traditional uses of alcohol, tobacco and other drugs, as well as the norms or social practices governing the use of specific substances within its specific culture. ${ }^{7}$

This research study revolves around the moderating effect presented by socio-cultural factors within the relationship between peer influence and drug use among the student population from eight different countries.

Noted that various studies have provided evidence to show the importance of peers in the development of substance use and abuse and the university environment seems to promote this strong peer influence. ${ }^{8}$ Some evidences show that the university environment provides a safe haven for experimentation with substance use. ${ }^{9}$ On the other hand, there are some protective factors to the use of drugs such as the effect of positive parenting practices influenced by the strength of family ties. ${ }^{10}$

This Multi-centric research study attempts to explore the cultural factors which correlate with drug consumption as well as the interactions of a specific set of psycho-social factors as moderators, namely religion/spirituality, entertainment and family relations among university students in seven universities across eight countries in Latin American and the Caribbean.

\section{METHOD}

This is a multi-centric study, cross-sectional in design, using the survey method to collect data in seven universities from eight countries in Latin America and the Caribbean. The sample consisted of undergraduate students between the ages of 18 and 24 years, attending two Caribbean and five Latin American universities. The total sample had 2198 people, representing a minimum of 250 and a maximum of 350 male and female students selected from each university. Students were from the Faculties of Social Sciences and Humanities/ Health Sciences. 
The dependent variable of the study was drug use. The licit drugs investigated were tobacco and alcohol and the illicit drugs were cannabis, cocaine and amphetamines. The independent variable of the study was the level of peer influence (number of friends who use drugs). The moderating variables were: quality of family relations, party-based entertainment (number of parties attended with the presence of drugs licit/illicit) and level of spirituality. The demographic variables investigated were: age, sex, academic registration status, marital/civil status, faculty, year of study/ semester and working status.

The students completed a retrospective, self-reported questionnaire about their substance use, entertainment, spiritual and family experiences. The questions were adapted from the Peer Influence Scale, the Index of Family Relations, the Spirituality Involvement and Beliefs Scale, a self-developed summated rating scale to measure entertainment engagement and an adaptation of questions one and two from the Alcohol, Smoking and Substance Involvement Screen Test. Statistical package for the Social Sciences (SPSS) version 15 was used for the design of the database and for data analysis. Descriptive statistical analyses, frequencies of categorical variables, measures of central tendency (means) and measures of dispersion (standard deviation) for numeric variables were conducted. Correlations and logistic regression analyses were also conducted to determine the relationship between friends who use drugs (peer influence) and drug use and the moderating effects of the socio-cultural factors on this relationship.

The findings of this study are intended to make inferences about the sample chosen from each university and not about the general university or wider populations. Therefore, the data obtained are limited in their ability to allow for predictive conclusions about any population beyond the samples.

\section{Instrument and measurement}

A self-report questionnaire was used to collect the data. The English version of the questionnaire was translated into Spanish and Portuguese taking into consideration the cultural meanings of words as well as the grammatical structure of sentences. The questionnaire, in the three languages of the study (English, Spanish and Portuguese) was piloted among persons within the 18-24 year age group and it took approximately 20-30 minutes to complete. The questionnaire consisted of six sections with 86 questions including: sociodemographic information (10 questions), peer influence (1), family relations (24), entertainment (1), spirituality (26), and drug consumption (5).

\section{The Index of Family Relations (IFR)}

The Index of Family Relations- IFR ${ }^{11}$ is a 25 items scale designed to measure the extent, severity, or magnitude of problems that family members have in their relationships with one another. The 25 items were responded on a 5-point scale ranging from "rarely or none of the time", to "most or all of the time."

The total score was computed by summing item scores and subtracting 25 . If items have been omitted, the score were calculated as $\mathrm{S}=(\mathrm{Y}-\mathrm{N})$ $(100) /[(N)(4)]$, where $\mathrm{N}$ was the number of items properly completed by the respondent.

\section{The Spiritual Involvement and Beliefs Scale (SIBS)}

The Spirituality Involvement and Beliefs Scale (SIBS) was developed by Hatch et al. ${ }^{12}$ The authors gave their authorization to use the scale via email on Thursday 25 $5^{\text {th }}$ August, 2011. The Spanish and Portuguese versions of the scale were also used in this multi-centric study. The instrument was a questionnaire containing 26 items in a modified Likert-type format. Therefore, the overall measure of spirituality was obtained by averaging the total response scores across the 26 items to arrive to a mean.

\section{The Alcohol, Smoking and Substance Involvement Screen Test (ASSIST)}

A modification of question one and two of the ASSIST was used in the study. These questions were developed by the World Health Organization. ${ }^{13}$ The questions relating only to alcohol, tobacco, cocaine, cannabis and amphetamines were selected. Questions F1 to F5 combined to form a 5 item measure in which the respondent was asked about the use of five drugs over the past 12 months. The respondent was expected to answer either "yes" or "no" to the use of drugs over this time period.

\section{Data collection}

The data were collected through the use of a self-reported questionnaire in each university 
from November 2011 to April 2012. Data were collected in and/or outside of classroom settings, on the conditions of the participating universities.

\section{Data analysis}

The data were analyzed using frequency, percentage, mean, measure of dispersion (standard deviation), median, cross tabulations, t-tests, correlation and logistic regressions. All demographic variables were analyzed and presented individually by University/City/Country. The data from all universities/cities/countries were combined in the evaluation of independent and moderating factors. Due to problems with the data collection in some countries and in order to ensure the quality of the data, there were some restrictions in the process of analysis:

- $\quad$ Drug use was considered only regarding the past 12 months.

- Peer influence was measured only by the number of friends who use drug.

- Entertainment was measured only by the number of parties with potential presence of drugs attended by the student in the past three months.

- In the evaluation of Family relationship the item The members of my family rarely care about each other was not considered in the analysis.

Ethical approval was obtained from the Research Ethics Board (REB) of the Centre for Addiction and Mental Health (CAMH) on November 2011 \# n. 136 and from the Ethical Committees from each participating university.

\section{RESULTS}

\section{Sociodemographic characteristics}

The sample in relation to age, sex and marital status distribution presented similar age patterns among the students from the different city/ countries, with very small deviation (average of 19.8-20.9 years old); the sample was composed predominantly $(50.0-79.1 \%)$ by females and single (62.4-82.0\%) students.

Regarding attendance to classes, the majority of students attended the university on full-time basis at all the studied universities, except in the university in Georgetown, Guyana, where only $12.2 \%$ of students fulfilled this condition.
In relation to the employment status of the sampled students, it was composed mainly by non-workers, independently of the university/ city/country, except for students from Georgetown/Guyana which have reported a percentage of employment superior to $30.0 \%$.

Regarding to the place of residence of the students and with whom they lived during the time of the study, in five of the eight sites studied, the majority of students lived at home with their families, but students from Florianopolis/Brazil referred to live predominantly in other places than with family, relatives or at the university residence. Students from San Jose, Costa Rica and from Kingston, Jamaica presented the higher percentage of them living at the university hall residence $(22.4 \%)$, in contrast to students from Bogota, Colombia, of which $89.4 \%$ lived at home with their families.

The distribution of area of study and academic year of enrollment of students participating in the study, by city and by country has pointed at some predominance of students attending courses in the Health Sciences area in the first two academic years; Bridgetown / Barbados, Georgetown/ Guyana and Kingston/Jamaica (69.2\%, 63.9\% and $84.8 \%$, respectively) had greater participation of Social Science students. Universities from San Salvador, Manabí and Florianopolis were those with higher participation of veteran students $\left(3^{\text {rd }}\right.$ year onwards) in the study.

\section{Use of licit and illicit drugs}

Table 1 shows the distribution of licit and illicit drug use in the past 12 months among the students participating in the study, by City and Country. Among the licit drugs, alcohol was the most used independent of university, city or country and only students from the university in San Salvador showed consumption below $50.0 \%$. In all other places consumption of alcohol varied from $52.8 \%$ in Manabi to $91.6 \%$ in Florianopolis. It was also clear in some countries the concomitant use of alcohol and tobacco. In relation to the use of illicit drugs, cannabis was the most consumed at all universities. Students from San Jose reported the highest consumption of all drugs studied, except alcohol for which students from Bogota and Florianopolis presented a higher percentage. The San Jose students reported particularly high use of Amphetamines and Cocaine in the past 12 months compared to other universities. 
Morera JAC, Parada AR, Ogowewo B, Gough H, Alava MMS, Zeferino MT, et al.

Table 1 - Distribution of licit and illicit drug use in the past 12 months among the students participating in the study, by City and Country

\begin{tabular}{lcccccccccc}
\hline & \multicolumn{3}{c}{ Licit drugs } & \multicolumn{7}{c}{ Illicit drugs } \\
\cline { 2 - 11 } City/Country & \multicolumn{2}{c}{ Alcohol } & \multicolumn{1}{c}{ Tobacco } & \multicolumn{1}{c}{ Cannabis } & \multicolumn{1}{c}{ Cocaine } & Amphetamines \\
\cline { 2 - 11 } & $\mathbf{n}$ & $\%$ & $\mathbf{n}$ & $\%$ & $\mathbf{n}$ & $\%$ & $\mathbf{n}$ & $\%$ & $\mathbf{n}$ & $\%$ \\
\hline $\begin{array}{l}\text { Bridgetown, Barbados } \\
\text { (n=250) }\end{array}$ & 193 & 77.2 & 37 & 14.8 & 38 & 15.2 & 5 & 2.0 & 2 & 0.8 \\
$\begin{array}{l}\text { Florianopolis/SC, Brazil } \\
\text { (n=250) }\end{array}$ & 229 & 91.6 & 86 & 34.4 & 76 & 30.4 & 1 & 0.4 & 7 & 2.8 \\
$\begin{array}{l}\text { Bogota, Colombia } \\
\text { (n=350) }\end{array}$ & 319 & 91.1 & 131 & 37.4 & 42 & 12.0 & 9 & 2.6 & 6 & 1.7 \\
$\begin{array}{l}\text { San Jose, Costa Rica } \\
\text { (n=250) }\end{array}$ & 213 & 85.2 & 139 & 55.6 & 160 & 64.0 & 35 & 14.0 & 63 & 25.2 \\
$\begin{array}{l}\text { Manabi, Ecuador } \\
\text { (n=250) }\end{array}$ & 132 & 52.8 & 61 & 24.4 & 14 & 5.6 & 10 & 4.0 & 10 & 4.0 \\
$\begin{array}{l}\text { San Salvador, El Salvador } \\
\text { (n=250) }\end{array}$ & 104 & 41.6 & 53 & 21.2 & 9 & 3.6 & 4 & 1.6 & 5 & 2.0 \\
$\begin{array}{l}\text { Georgetown, Guyana } \\
\text { (n=263) }\end{array}$ & 159 & 60.5 & 29 & 11.0 & 24 & 9.1 & 11 & 4.2 & 7 & 2.7 \\
$\begin{array}{l}\text { Kingston, Jamaica } \\
\text { (n=335) }\end{array}$ & 262 & 78.2 & 51 & 15.2 & 47 & 14.0 & 1 & 0.3 & 3 & 0.9 \\
\hline
\end{tabular}

Table 2 presents the average number of friends on drugs of the students participating in the study, by city and by country. Independently of university, there was a predominance of some and most friends on drugs $(50.4 \%)$ and students from Florianopolis,
Brazil (77.2\%) reported the highest percentage of most friends on drugs while university students from Kingston, Jamaica reported the lowest percentage of most friends on drugs $(11.0 \%)$, as well as the highest percentage of no friends on drugs $(20.0 \%)$.

Table 2 - Distribution of Peer influence (number of friends on drugs) of the students participating in the study, by City and by Country

\begin{tabular}{lcccccccccc}
\hline & \multicolumn{8}{c}{ Number of friends on drugs } \\
\cline { 2 - 11 } City/Country & \multicolumn{2}{c}{ None } & \multicolumn{1}{c}{ One } & \multicolumn{1}{c}{ Few } & \multicolumn{3}{c}{ Some } & \multicolumn{3}{c}{ Most } \\
\cline { 2 - 11 } & $\mathbf{n}$ & $\%$ & $\mathbf{n}$ & $\%$ & $\mathbf{n}$ & $\%$ & $\mathbf{n}$ & $\%$ & $\mathbf{n}$ & $\%$ \\
\hline $\begin{array}{l}\text { Bridgetown, Barbados } \\
\text { (n=275) }\end{array}$ & 24 & 9.6 & 6 & 2.4 & 105 & 42.0 & 66 & 26.4 & 49 & 19.6 \\
$\begin{array}{l}\text { Florianopolis, SC/Brazil } \\
\text { (n=250) }\end{array}$ & 23 & 9.2 & - & - & 34 & 13.6 & 60 & 24.0 & 133 & 53.2 \\
$\begin{array}{l}\text { Bogota, Colombia } \\
\text { (n=350) }\end{array}$ & 24 & 6.9 & 13 & 3.7 & 76 & 21.7 & 136 & 38.9 & 101 & 28.9 \\
$\begin{array}{l}\text { San Jose, Costa Rica } \\
\text { (n=250) }\end{array}$ & 4 & 1.6 & 21 & 8.4 & 78 & 31.2 & 79 & 31.6 & 68 & 27.2 \\
$\begin{array}{l}\text { Manabi, Ecuador } \\
\text { (n=250) }\end{array}$ & 35 & 14.0 & 11 & 4.4 & 72 & 28.8 & 81 & 32.4 & 51 & 20.4 \\
$\begin{array}{l}\text { San salvador, El Salvador } \\
\text { (n=143) }\end{array}$ & 13 & 9.1 & 20 & 14.0 & 33 & 23.1 & 37 & 25.9 & 40 & 28.0 \\
$\begin{array}{l}\text { Georgetown, Guyana } \\
\text { (n=263) }\end{array}$ & 48 & 18.3 & 10 & 3.8 & 111 & 42.2 & 54 & 20.5 & 40 & 15.2 \\
$\begin{array}{l}\text { Kingston, Jamaica } \\
\text { (n=335) }\end{array}$ & 67 & 20.0 & 13 & 3.9 & 140 & 41.8 & 76 & 22.7 & 37 & 11.0 \\
\hline
\end{tabular}




\section{Moderating and independent variables}

Table 3 presents the average scores from the moderating and independent variables referred by university students according to city and country. Considering a scale varying from 0-100, the family relationship results varied from 21.20 in San Salvador, El Salvador to 46.90 in Georgetown, Guyana. These scores were designed in such way that higher scores indicated greater magnitude or severity of problems. Party based entertainment, measured as the number of parties where alcohol, tobacco, or mood altering substances may have been present in parties attended by the student in the past three months, varied from 1.70 in San Salvador, El Salvador to 8.16 in Florianopolis, Brazil. Peer influence was measured as the number of friends who smoke, drink alcohol or use other forms of drugs. It varied from 2.02 in Kingston, Jamaica to 3.12 in Florianopolis, Brazil. Peer influence in San Salvador, El Salvador showed a large number of missing data (42.80\%). Spirituality was measured on a scale from $0-5$, where five shows the greater spirituality and presented the most stable results of all variables between cities, varying from 3.21 in Manabi, Ecuador to 3.74 in San Salvador, El Salvador.

Table 3 - Moderating and Independent variables of the study by City/Country

\begin{tabular}{|c|c|c|c|c|c|c|c|c|}
\hline Item & $\begin{array}{l}\text { Bridgetown } \\
\text { Barbados } \\
(\mathrm{n}=250) \\
\text { Mean } \\
\text { (sd) }\end{array}$ & $\begin{array}{l}\text { Florianopolis } \\
\text { Brazil } \\
\qquad \begin{array}{c}(\mathrm{n}=250) \\
\text { Mean } \\
(\mathrm{sd})\end{array}\end{array}$ & $\begin{array}{c}\text { Bogota } \\
\text { Colombia } \\
\text { (n=350) } \\
\text { Mean } \\
\text { (sd) }\end{array}$ & $\begin{array}{c}\text { San Jose } \\
\text { Costa } \\
\text { Rica } \\
(n=250) \\
\text { Mean } \\
(\text { sd) } \\
\end{array}$ & $\begin{array}{c}\text { Manabi } \\
\text { Ecuador } \\
(\mathrm{n} 250) \\
\text { Mean } \\
\text { (sd) } \\
\end{array}$ & $\begin{array}{c}\text { San } \\
\text { Salvador } \\
\text { El Salvador } \\
(n=250) \\
\text { Mean } \\
\text { (sd) }\end{array}$ & $\begin{array}{l}\text { Georgetown } \\
\text { Guyana } \\
(\mathrm{n}=250) \\
\text { Mean } \\
\text { (sd) }\end{array}$ & $\begin{array}{c}\text { Kingston } \\
\text { Jamaica } \\
(\mathrm{n}=332) \\
\text { Mean } \\
\text { (sd) } \\
\end{array}$ \\
\hline $\begin{array}{l}\text { Friend who } \\
\text { use drugs }\end{array}$ & 2.44 & 3.12 & 2.79 & 2.74 & 2.41 & 2.5 & 2.11 & 2.02 \\
\hline (Independent) & (1.13) & (1.22) & (1.11) & $(1.00)$ & (1.26) & $(1.28)$ & $(1.26)$ & (1.24) \\
\hline $\begin{array}{l}\text { Family } \\
\text { relationship }\end{array}$ & 36.5 & 33.2 & 22.1 & 45.1 & 34.5 & 21.2 & 46.9 & 33.8 \\
\hline (Moderating) & (22.8) & (22.8) & $(16.4)$ & $(28.5)$ & $(23.5)$ & (21.5) & $(24.7)$ & $(23.1)$ \\
\hline $\begin{array}{l}\text { Party based } \\
\text { entertainment }\end{array}$ & 2.49 & 8.16 & 3.95 & 6.88 & 2.33 & 1.7 & 1.54 & 2.52 \\
\hline (Moderating) & (4.58) & $(8.00)$ & (5.56) & $(7.69)$ & (3.10) & (2.95) & (3.61) & $(3.79)$ \\
\hline Spirituality & 3.52 & 3.47 & 3.42 & 3.5 & 3.21 & 3.74 & 3.64 & 3.63 \\
\hline (Moderating) & $(0.58)$ & $(0.5)$ & $(0.5)$ & $(0.49)$ & $(0.44)$ & $(0.55)$ & $(0.54)$ & $(0.56)$ \\
\hline
\end{tabular}

Relationship between friends who use drugs, spirituality, family relationship, party ased entertainment and licit and illicit drug use in the last 12 months

Table 4 presents the association between friends who use drugs, family relationship, spirituality and party-based entertainment and licit and illicit drug use in the last 12 months, adjusted for demographic, school and work status characteristics. The results indicated that friends who use drugs are significantly associated with licit drug use $(p<0.000)$. More specifically, individuals with a greater number of friends who use drugs are at greater odds of using alcohol or tobacco $(\mathrm{OR}=1.582)$. Greater party-based entertainment activities are also associated with greater odds of using alcohol or tobacco $(\mathrm{p}<0.000)$. In contrast, greater spirituality is associated with lower odds of using alcohol or tobacco $(\mathrm{p}<0.000, \mathrm{OR}=0.637)$. The same kind of analysis considering illicit drugs showed that family relationship $(p=0.004)$, party-based entertainment $(p<0.000)$ and friends who use drugs $(p<0.000)$ were significantly associated with youths illicit drug use. Family relationship $(\mathrm{OR}=1.022)$, party-based entertainment $(\mathrm{OR}=1.079)$ and peer influence $(\mathrm{OR}=1.719)$ all increased the odds of youths using illicit drugs; however, the influence of friends who use drugs had the greatest odds of youths using illicit drugs. Spirituality had no impact on youths' likelihood of illicit drug use in the past 12 months ( $p>0.05$; $\mathrm{OR}=0.856$ ). 
Table 4 - Relationship between friends who use drugs, spirituality, family relationship, party based entertainment and licit and illicit drug use in the last 12 months

\begin{tabular}{lcccccccc}
\hline \multirow{1}{*}{\multicolumn{1}{c}{ Variables }} & \multicolumn{4}{c}{ Licit drugs } & \multicolumn{4}{c}{ Illicit drugs } \\
\cline { 2 - 8 } & p-Value & OR & $\begin{array}{c}\text { Lower } \\
\text { IC 95\% }\end{array}$ & $\begin{array}{c}\text { Upper } \\
\text { IC } \\
\text { 95\% }\end{array}$ & p-Value & OR & $\begin{array}{c}\text { Lower } \\
\text { IC }\end{array}$ & $\begin{array}{c}\text { Upper } \\
\text { IC }\end{array}$ \\
& & & 95\% & $\mathbf{9 5 \%}$ \\
\hline Age & 0.328 & 1.043 & 0.959 & 1.134 & 0.002 & 0.878 & 0.809 & 0.954 \\
Faculty-Health Sci (ref=social sc) & 0.736 & 1.046 & 0.804 & 1.363 & 0.189 & 0.839 & 0.646 & 1.090 \\
Gender - female (ref=male) & 0.902 & 0.982 & 0.741 & 1.303 & 0.000 & 0.482 & 0.375 & 0.620 \\
Marriage status - single (ref=other) & 0.177 & 0.826 & 0.626 & 1.091 & 0.030 & 1.382 & 1.032 & 1.851 \\
Registration status - full-time & 0.225 & 1.212 & 0.888 & 1.653 & 0.063 & 1.371 & 0.983 & 1.911 \\
(ref=part-tm) & 0.833 & 0.969 & 0.723 & 1.299 & 0.000 & 0.498 & 0.386 & 0.644 \\
Residence - at home (ref=other) & 0.373 & 0.864 & 0.627 & 1.191 & 0.761 & 0.950 & 0.683 & 1.321 \\
Work status - working (ref=no wrk) & 0.014 & 0.862 & 0.765 & 0.971 & 0.305 & 1.067 & 0.943 & 1.206 \\
Year of study & 0.000 & 1.582 & 1.422 & 1.76 & 0.000 & 1.581 & 1.397 & 1.790 \\
Friends who use drugs & 0.290 & 0.997 & 0.992 & 1.002 & 0.000 & 1.016 & 1.010 & 1.021 \\
Family relationship & 0.000 & 0.637 & 0.500 & 0.812 & 0.206 & 0.857 & 0.675 & 1.089 \\
Spirituality & 0.000 & 1.393 & 1.287 & 1.507 & 0.000 & 1.080 & 1.058 & 1.102 \\
Party based entertainment & 0.321 & & & & 0.005 & & & \\
Intercept & & & & & & & &
\end{tabular}

Table 5 outlines the association between friends who use drugs, spirituality, family relationship, party based entertainment and licit drug use last 12 months including the interaction party based entertainment friends who use drugs. Findings indicate that the interaction between party-based entertainment friends who use drugs $(p=0.001)$ are significantly associated with licit drug use. This interaction indicates that the effect of friends who uses drugs on the odds (OR=0.897) of students using alcohol and/ or tobacco is reduced as the number of parties attended increases. The association between family relationship, party-based entertainment, friends who use drugs and spirituality on youths' illicit drug use in the 12 months preceding the survey, after adjusting for demographic, school and work status characteristics indicate that the interaction between spirituality and friends who use drugs $(p>0.05)$ was not associated with illicit drug use.

Table 5 - Relationship between friends who use drugs, spirituality, family relationship, party based entertainment and licit drug use last 12 months including the interaction of party based entertainment and friends who use drugs

\begin{tabular}{|c|c|c|c|c|c|c|}
\hline Variables & Estimate & $\begin{array}{c}\text { Standard } \\
\text { error }\end{array}$ & p-value & $\begin{array}{l}\text { Odds } \\
\text { Ratio }\end{array}$ & $\begin{array}{c}\text { Lower 95\% C.I. } \\
\text { Odds Ratio }\end{array}$ & $\begin{array}{c}\text { Upper } 95 \% \text { C.I. } \\
\text { Odds Ratio }\end{array}$ \\
\hline Age & 0.046 & 0.043 & 0.285 & 1.047 & 0.962 & 1.139 \\
\hline Faculty- Health Sci (reference=social sc) & 0.044 & 0.136 & 0.746 & 1.045 & 0.800 & 1.364 \\
\hline Gender - female (reference=male) & -0.010 & 0.145 & 0.945 & 0.990 & 0.745 & 1.316 \\
\hline Marriage status - Single (ref=other) & -0.196 & 0.143 & 0.171 & 0.822 & 0.621 & 1.089 \\
\hline Registration status - Full-time (ref=part-tm) & 0.162 & 0.160 & 0.313 & 1.175 & 0.859 & 1.609 \\
\hline Residence - at home (ref=other) & -0.010 & 0.151 & 0.950 & 0.991 & 0.737 & 1.331 \\
\hline Work status - Working (ref=no wrk) & -0.160 & 0.165 & 0.333 & 0.853 & 0.617 & 1.178 \\
\hline Year of study & -0.151 & 0.061 & 0.014 & 0.860 & 0.762 & 0.970 \\
\hline Friends who use drugs & 0.564 & 0.063 & 0.000 & 1.758 & 1.553 & 1.990 \\
\hline Family relationship & -0.003 & 0.003 & 0.323 & 0.997 & 0.992 & 1.003 \\
\hline Spirituality & -0.441 & 0.125 & 0.000 & 0.643 & 0.504 & 0.821 \\
\hline Party based entertainment & 0.631 & 0.105 & 0.000 & 1.879 & 1.530 & 2.308 \\
\hline Party friends who use drugs & -0.109 & 0.032 & 0.001 & 0.897 & 0.842 & 0.956 \\
\hline Intercept & 0.632 & 1.003 & 0.529 & & & \\
\hline
\end{tabular}


Table 6 describes the association between family relationship, party-based entertainment, friends who use drugs and spirituality on youths' illicit drug use in the 12 months preceding the survey, after adjusting for demographic, school and work status characteristics. The findings show that the interaction between party-based entertainment friends who use drugs lowered the odds of university students using illicit drugs $(\mathrm{p}=0.015$; $\mathrm{OR}=0.975$ ). The association between family re- lationship, party-based entertainment, friends who use drugs, spirituality and the interaction Family Relationship*Friends who use drugs on youths' illicit drug use in the 12 months preceding the survey, adjusted for demographic, school and work status characteristics, showed that the interaction between family relationship* friends who use drugs was not associated with illicit drug usage $(p>0.05)$.

Table 6 - Relationship between friends who use drugs, spirituality, family relationship, party based entertainment and illicit drug use last 12 months, including the interaction party based entertainment friends who use drugs

\begin{tabular}{lccccccc}
\hline \multicolumn{1}{c}{ Variables } & Estimate & Standarderror & $\begin{array}{c}\text { Wald Chi- } \\
\text { Square }\end{array}$ & $\begin{array}{c}\text { Prob> } \\
\text { Chi-Square }\end{array}$ & $\begin{array}{c}\text { Odds } \\
\text { Ratio }\end{array}$ & $\begin{array}{c}\text { Lower 95\% } \\
\text { C.I. Odds } \\
\text { Ratio }\end{array}$ & $\begin{array}{c}\text { Upper 95\% } \\
\text { C.I. Odds } \\
\text { Ratio }\end{array}$ \\
\hline Age & -0.125 & 0.042 & 8.850 & 0.003 & 0.883 & 0.813 & 0.958 \\
Faculty & -0.177 & 0.134 & 1.754 & 0.185 & 0.838 & 0.645 & 1.089 \\
Family relationship & 0.015 & 0.003 & 33.996 & 0.000 & 1.015 & 1.010 & 1.021 \\
Gender & -0.721 & 0.128 & 31.587 & 0.000 & 0.486 & 0.378 & 0.625 \\
Intercept & -0.339 & 0.989 & 0.118 & 0.732 & 0.000 & $<0.001$ & $<0.001$ \\
Marriage status & 0.351 & 0.150 & 5.477 & 0.019 & 1.421 & 1.059 & 1.907 \\
Party friends who use drugs & -0.025 & 0.011 & 5.864 & 0.015 & 0.975 & 0.955 & 0.995 \\
Party based entertainment & 0.157 & 0.035 & 20.058 & 0.000 & 1.170 & 1.092 & 1.253 \\
Friends who use drugs & 0.566 & 0.079 & 51.186 & 0.000 & 1.761 & 1.508 & 2.056 \\
Registration status & 0.306 & 0.170 & 3.240 & 0.072 & 1.358 & 0.973 & 1.896 \\
Residence & -0.680 & 0.131 & 26.964 & 0.000 & 0.507 & 0.392 & 0.655 \\
Spirituality & -0.151 & 0.122 & 1.519 & 0.218 & 0.860 & 0.677 & 1.093 \\
Work status & -0.051 & 0.168 & 0.093 & 0.761 & 0.950 & 0.683 & 1.321 \\
Year of study & 0.052 & 0.063 & 0.686 & 0.408 & 1.054 & 0.931 & 1.193 \\
\hline
\end{tabular}

\section{DISCUSSION}

The findings showing alcohol and/or tobacco as the main drugs used by the students are corroborated by a previous study developed among South American and Caribbean university students on simultaneous polydrug use. The results of this study showed that alcohol and tobacco were the most prevalent association of drugs reported in the past year as well as in the past 30 days prior to the survey. ${ }^{14}$ The different pattern of alcohol and/or tobacco use presented by the countries and in particular by regions (South America and Caribbean) could be explained partially by social cultures and social acceptance of alcohol and tobacco among each culture. Therefore, in some cultures the use of alcohol at social occasions and in small to moderate amounts seems natural and part of the culture. Also, the differences between Latin American and Caribbean Countries could be explained due to different religious patterns and in this direction, several studies have shown the protective effect of religion regarding alcohol use. ${ }^{15-17}$ According to these authors, higher religiosity is associated with a less likelihood to initiate or to use/abuse alcohol and or tobacco. This fact may also explain the protective influence of higher spirituality on use of licit drugs.

The fact that the questions about the use of licit drugs did not quantify the use has limited the results and potential associations between the modifying variables. The non-significance of the interaction Family relationship Friends who use drugs on the use of alcohol and/or tobacco may have been affected by the lack of effect of Family relationship, but also Friends who use drugs (Peer influence) may have presented some limitation as independent variable, since the question evaluating it did not distinguish between the amounts or the frequency of drug use, nor whether the use was related to Licit or Illicit drugs. The social and 
cultural aspects could have played statistically a more important role on alcohol and tobacco use than Family relationship, and these aspects appear to be independent of the quality of family relationship.

The statistically significant interaction identified on Friends who use drugs Party based entertainment showing a decrease in the odds of students using alcohol and/or tobacco as the number of parties increases could have resulted from the fact that the variable Peer influence, measured as the number of friends on drugs, did not separate friends who use licit drugs (alcohol and tobacco) from friends who use illicit drugs (cannabis, cocaine, Amphetamine-type stimulants). Since the use of alcohol (not the abuse) is present in the everyday life of most students and families houses as well as in the large majority of parties, it may have contributed to these results. In relation to the association of high number of friends who use drugs, problematic family relationship and high number of parties attended with the increased odds of use of illicit drugs by the university students, it is difficult to identify the individual variables associations, since they are very closely associated between themselves. It has been found that teenagers with a good relationship with their parents are less likely to choose friends who use drugs. ${ }^{10}$ The selection of friends who use drugs can be done based on two main ways: by socialization- where the peers influence each other's behaviours depending, in general, on the existing or perceived norms within the group or social context, or by selection - where the individual looks for or associates himself/herself to a friend or group with a similar behaviour or attitude. ${ }^{8}$ In the case of illicit drugs, individuals who are interested in a specific kind of drug use may choose to associate themselves to individuals with common interests. ${ }^{18}$

The association between party based entertainment and the use of illicit drugs rely mainly on dance parties. These parties, in particular "rave" and "funk" type, which are in general very permissive in relation to drugs use/abuse, are very closely associated with youth culture. ${ }^{4}$ Considering the strong negative association between spirituality and use of alcohol and/or tobacco by the students and the lack of association between spirituality and the use of illicit drugs, it could be partially understood by the theoretical approach in which alcohol and tobacco work as route to illicit drugs ("gateway model"). It is possible that many of those students using illicit drugs come from the parcel of students with lower spirituality, or even from those in which the level of spirituality did not interfere with drug use, independent of being licit or illicit. Several studies have shown that the use of substances such as alcohol and tobacco, alone or combined, are a risk factor for illegal drugs use among young people. ${ }^{19}$

\section{CONCLUSIONS}

The use of licit drugs presented large variability among universities/Cities/Countries with some potential cultural/religious influence on its use. This variability became clearer when comparing South American and Caribbean countries. The number of friends using drugs and party-based entertainment are statistically associated with licit drug use. On the other hand, higher spirituality is associated with lower odds of alcohol and tobacco use. In relation to illicit drug use, problematic family relationship, high number of party-based entertainment and high number of friends on drugs (peer influence) increased the odds of youths using illicit drugs. Individually, friends who use drugs was the strongest factor associated with the increased odds of university students using licit and/or illicit drugs. The level of spirituality influence positively on consumption of licit drugs (alcohol and tobacco), but did not show significant effect on consumption of illicit drugs. Problematic family relationship did not interfere significantly in the odds of student use of alcohol and tobacco. Friends who use drugs and party based entertainment were the only interaction that increased the odds of students consuming both licit and illicit drugs.

\section{Limitations}

Peer influence might have been overestimated as it was measured based only on the number of friends on drugs, and it did not separately evaluate those on licit drugs (alcohol and tobacco) and those on illicit drugs. It should be considered that in most cultures in South American countries and some in the Caribbean, the use or experimentation of alcohol and tobacco is seen as part of the general social circles, and do not necessarily represent a situation with a higher risk. The analyses of party entertainment based only on number of parties attended by the student with potential presence of drugs (licit and/or illicit) has limited the associations and potential conclusions, since in most 
Latin American cultures the presence of alcohol in parties, with few exceptions, is very common.

\section{Recommendations}

We recommend to CICAD, the Governments of participant countries, and the universities to consider the findings of this study in the development and implementation of new research studies with University students, as well as the findings generated from other studies prepared by the participants of the CICAD/CAMH International Research Capacity-Building Program. These research results can bring important information for the development of preventive and health promotion programs designed to university students.

\section{Acknowledgment}

The Organization of America States, InterAmerican Drug Control Commission (CICAD/ OAS), the Government of Canada/DFAIT and the Centre for Addiction and Mental Health (CAMH), Toronto-Canada for supporting and endorsing this project financially and technically; to the selected Universities in Latin America and the Caribbean for their invaluable support; as well as other collaborators and the students who participated in the research.

\section{REFERENCES}

1. United Nations Office of Drug Consumption. Bulletin on narcotics: the practice of drug abuse epidemiology. 2003 [access 2014 Aug 14]; 55(1/2). Available at : http://www.unodc.org/pdf/ bulletin/bulletin_2003_01_01_1.pdf

2. Shifter M. Latin America's drug problem. Current History. 2007 Feb [access 2014 Aug 14]; 58-63 Available in at http://www.hacienda.go.cr/centro/ datos/Articulo/Latin\%20America \% 20drug \% 20 problem.pdf

3. United Nations Office of Drug Consumption. UNODC: Promoting health, security and justice: cutting the threads of drugs crime and terrorism 2010 report. UNODC; 2010 [access 2014 Aug 15] Available at https://www.unodc.org/documents/frontpage/ UNODC_Annual_Report_2010_LowRes.pdf

4. Measham F, Parker H, Aldridge J. Teenage transition from adolescent recreational drug use to the young adult dance culture in Britain in the mid 1990's. J Drug Iss. 1998 Winter; 28(1):9-32.

5. Orozco JB. Analisis de brechas y determinación de prioridades en la investigación sobre reducción de la demanda de drogas en America Latina. Madrid (ES): Consorcio COPOLAD; 2013. [access 2014 Aug
16] Available at: https://www.copolad.eu/c/ document_library /get_file?uuid=ab72d11f-bd7d4fe5-ab98-aa0f3f2e6996\&groupId=10157

6. QeC-ERAN. National Action Plan on Social Inclusion. 2005 [Access 2014 Aug 14] Available at: http://www.ludenet.org/archives/qeceran/ projects/lapsraps_index.htm

7. United Nations Office of Drug Consumption, UNODC. Drug abuse prevention among youth from ethnic and indigenous minorities. Global Youth Network 2004. [Access 2014 Aug 15] Available at: https://www.unodc.org/pdf/youthnet/ handbook_ethnic_english.pdf

8. Andrews J, Hops H. The influence of peers on substance use. In: Scheier LM, Handbook of drug use etiology: theory, methods, and empirical findings. $3^{\text {rd }}$ ed,. Washington, DC: American Psychological Association; 2002.

9. Pandina RJ, Johnson VL, White HR. Peer influence on substance use during adolescence and emerging adulthood. In: Scherie LM. Handbook of drug use etiology: theory, methods, and empirical findings. $3^{\text {rd }}$ ed. Washington D.C: American Psychological Association; 2002.

10. Urberg KA, Luo Q, Pilgrim C, Degirmencioglu SM. A two-stage model of peer influence in adolescent substance use: Individual and relationship-specific differences in susceptibility to influence. Addict Behaviors, 2003 Sept; 28(7):1243-56.

11. Hudson WW. The WALMYR Assessment scales scoring manual. Tempe, AZ: WALMYR Publishing Co; 1992.

12. Hatch RL, Burg MA, Naberhaus DS, Hellmich LK. The Spiritual Involvement and Beliefs Scale development and testing of a new instrument. J Fam Pract. 1998 Jun; 46(6):476-86.

13. World Health Organization. The Alcohol, Smoking and Substance Involvement Screening Test (ASSIST) manual for use in primary care. WHO Press; 2010. [access 2014 Aug 16] Available at: http:/ / whqlibdoc. who.int/publications/2010/9789241599382_eng. pdf

14. CICAD. O problema das drogas nas Américas - Relatório analítico. 2013 [access 2014 Aug 15] Available at http:/ / www.oas.org/documents/por/ press/reporte_drogas_OEA_POR.pdf]

15. Hadaway CK, Elifson KW, Petersen DM. Religious involvement and drug use among urban adolescents. J Scientific Study Religion 1984 Jun; 23(1):109-28.

16. Hawks RD, Bahr SH. Religion and drug use. J Drug Educ. 1992 Jan-Mar; 22(1):1-8.

17. Cochran JK, Beeghley L, Bock EW. The influence of religious stability and homogamy on the relationship between religiosity and alcohol use among protestants. J Scientific Stud Religion. 1992 [access 2014 Aug 14]; 31(4):441-56 Available at http://www.jstor.org/stable/1386855 
18. Ennett ST, Bauman KE. The contribution of influence and selection to adolescent peer group homogeneity: the case of adolescent cigarette smoking. J Pers Soc Psychol. 1994 Oct; 67(4):653-63.
19. Herrera-Vázquez M, Wagner FA, VelascoMondragon E, Borges G, Loscano-Ponce E. Inicio en el consumo de alcohol y tabaco y transición a otras drogas en estudiantes de Morelos, México. Salud Publica Mex. 2004 Mar-Abr; 46(2):132-40. 